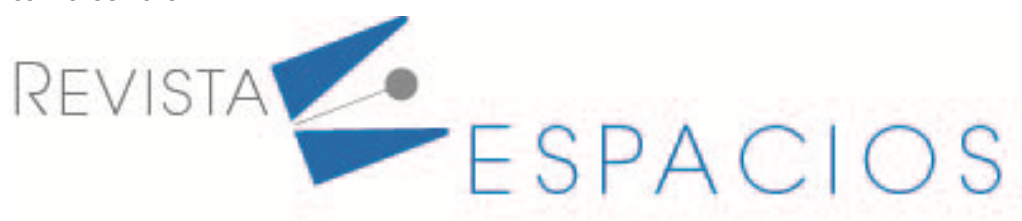

Vol. 41 (49) $2020 \cdot$ Art. 8

Recibido/Received 18/09/2020 • Aprobado/Approved: 05/11/2020 • Publicado/Published: 23/12/2020

\title{
Improving the quality of management based on internal control system
}

\author{
Mejora de la calidad de la gestión basada en el sistema de control interno
}

OVCHINNIKOVA, OIga A. ${ }^{1}$

GREBNEVA, Marina E. ${ }^{2}$

\begin{abstract}
The management system effects on its object through general functions. Relationship and interaction of these functions create a close control cycle. The control is the leading management function. This paper discusses the goals of building an effective internal control system that generates reliable information for making management decisions. The authors structure the internal control system and research sources of information base for its functioning. Moreover they select methods of quality assessment of the internal control system and formulate the stages of evaluation of its effectiveness in an enterprise.

Keywords: quality of management; management decisions; internal control system; methodology for evaluating the internal control system

\section{Resumen}

El sistema de control actúa sobre el objeto controlado a través de funciones comunes, cuya conexión e interacción forman un bucle de control cerrado. Control esta es la función principal de administración. Los autores estructuran el sistema de control interno y las fuentes de información de investigación para su funcionamiento. Además, seleccionan métodos de evaluación de la calidad del sistema de control interno y formulan las etapas de evaluación de su eficacia en una empresa.

Palabras clave: calidad de la gestión; Las decisiones de gestión; sistema de control interno; Metodología de evaluación del sistema de control interno
\end{abstract}

\section{Introduction}

Management is a systematic, conscious, purposeful impact on the process of social work or other activities aimed at achieving the goal by making the most effective use of financial, material, labor and other resources. The decisions accepted during a managing a company relate to a huge variety of problems arising in different periods of time. A manager ought to get a high-quality and reliable information to provide an effective management decision. The main source of this information is an accounting data. There is the need of control of each stage of formation, measurement, registration and generalization of accounting information to meet the requirements of the management system for accounting information. The system of internal control is a set of rules and

\footnotetext{
${ }^{1}$ Department of finance, credit and accounting. Kursk State University, ul. Radishcheva 29, Kursk, 305000, The Russian Federation. E-mail: lelika46@yandex.ru

${ }^{2}$ Department of finance, credit and accounting. Kursk State University, ul. Radishcheva 29, Kursk, 305000, The Russian Federation. E-mail: mgrebneva@mail.ru
} 
algorithms for the implementation of control and audition procedures aimed at ensuring the safety of material and financial resources of the company by monitoring the accuracy of all facts of economic activity and the correctness of the accounting.

Within the control there are such management functions as: a comparison between the planned and actually achieved results; calculation of deviations between actual results and plan and identification of their causes; removal of the causes of deviations of actuals from the plan.

It is necessary to regularly evaluate the system of internal control to improve its effectiveness by identifying reserves in this area of management. This evaluation is aimed at achieving a number of goals that may improve the quality of company's management and increase the efficiency of its functioning.

\section{Methodology}

The control system effects on the managed object through general functions, the which relationship and interaction form a closed control cycle. C. Drury identifies the following sequence of general management functions: planning, control, organization, communication, and motivation (Drury, 2017). in this continuous process, control plays a special role. It helps to verify the available data, numbers and information and makes the accounting information suitable for making management decisions.

S. A. Makarenko considers that among the main goals of developing an effective system of internal control of the company it is necessary to include the following:

- research on issues of control over the safety of property, tangible and financial assets;

- achieving a high level of efficiency in using the available resource and financial potential;

- development of an effective system for identifying and managing the risks of economic activity of the company;

- formation of reliable and complete information about the results of economic activity of the company;

- assessment of the level of compliance with legislation and requirements of regulatory legal acts in the implementation of economic activities of the company (Makarenko, 2018).

The need to build a high-quality internal control system of the company is also reflected at the legislative level.

The internal control system of an economic entity includes the following main elements, shown in figure 1.

Figure 1

Elements of the internal control system

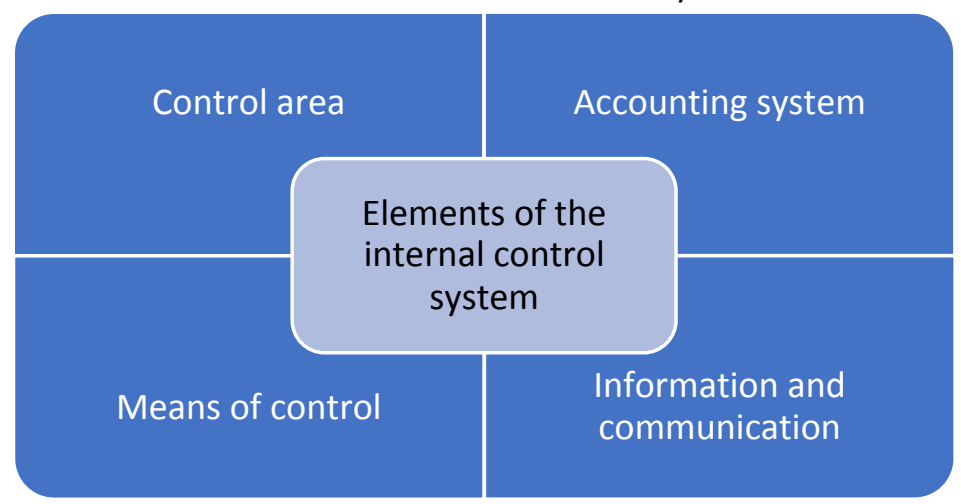


It consider necessary to expand the list of elements of the internal control system by including risk assessment procedures. During the investigation of the risks of the internal control system it is necessary to take into account all possible risks from fraud to the risk of sampling errors and representativeness. The authors believe that risk management is one of the key functions of the internal control system in the conditions of varying external impact (Egorova, 2015; Zelenskaya, 2016).

The first issue that be considered when building an internal control system of company is the formation of an information base for conducting these control procedures. As noted by O. P. Zaitseva, the main element of forming the information base for internal control is the materials and data of accounting and reporting of the company. The extended list of sources of information base formation for the internal control system includes:

- internal regulations and standards for accounting procedures and implementing the accounting process;

- accounting financial and internal reporting of an economic entity;

- information databases used in the company for certain business processes;

- system of legal documentation regulating the company's activities;

- a set of planned and forecast documentation, as well as operational and analytical information (Zaitseva. 2016).

It is possible to achieve an effective assessment of the internal control system through the use of a certain set of requirements which may include:

- validity (evaluation of quality of the internal control system should be based on documents and confirmed professional conclusions);

- coherence (the conclusions and judgments regarding the quality of the internal control system should not contradict other relevant conclusions);

- consistency (the assessing of quality of internal control should include a systematic approach that takes into account all the elements and facts of this process);

- objectivity (lack of personal or private interest in the study of facts that characterize the quality of the internal control system).

The methodology for evaluating the internal control system of company involves the use of certain tools. The main methods for assessing the quality of the internal control system include the following:

- application of expert methods based on the use of a marking system;

- use of "maturity models", which disclose a list of features and criteria which allow us to understand the level of "maturity" and the effectiveness of the internal control system;

- applicationof a certainsetofstandardsandcontrolrequirementswhichgivereasontofind a high level of quality of the internal control system;

- use of tests and control questions that help to form an opinion on the level of effectiveness of the internal control system of an economic entity.

An assessment of an internal control system of company should be based on a specific set of principles. A number of principles for evaluating the effectiveness of the internal control system are described in the publications of T. V. Samoilova and M. S. Uzlov. Based on the generalization of materials published by these authors, we highlight the most significant principles in this area of research: 
- the principle of functionality - a clear division of powers between both individuals who carry out control procedures, and between subjects of control;

- the principle of regulation - the existence of a clear and verified legal framework that ensures the legitimacy and legality of control procedures (Uzlov, 2016);

- the principle of complexity - internal control measures and tools should cover all business operations;

- the principle of optimality - the most optimal and effective control tools should be used when implementing internal control procedures (Samoilova, 2015).

G. V. Maksimova considers it appropriate to use three stages of evaluating the internal control system of an economic entity:

- formation of general ideas about the internal control system as a whole and its main elements;

- qualitative and / or quantitative risk assessment of the control area and the use of individual controls;

- testing of the control procedure (Maksimova, 2017).

\section{Results}

Assessment of the quality of the internal control system includes three main elements:

- resource potential and structural characteristics of the internal control system;

- stages in the implementation of procedures for the functioning of the internal control system of an economic entity;

- the level of effectiveness of the internal control system.

The methodology for evaluating the internal control system requires certain procedures. The main procedures for implementing internal control in the company's activities include:

- documentary registration;

- identification of the correspondence between the actual and accounting values of the internal control object;

- authorization of conducting economic operations;

- assessment of the competence to make managerial decisions;

- qualitative and quantitative reconciliation of data in the context of individual objects of control (Quintero Quintero, 2019).

Evaluation of the effectiveness of the company's internal control system should be carried out in several main stages. Compliance with the sequence of these stages is the key to achieving high results in improving the quality of the internal control system. The main stages of evaluating the effectiveness of the internal control system are shown in figure 2. 
Figure 2

Main stages of evaluating the effectiveness

of the internal control system of company

Familiarization with the internal control system and its features in the certain company

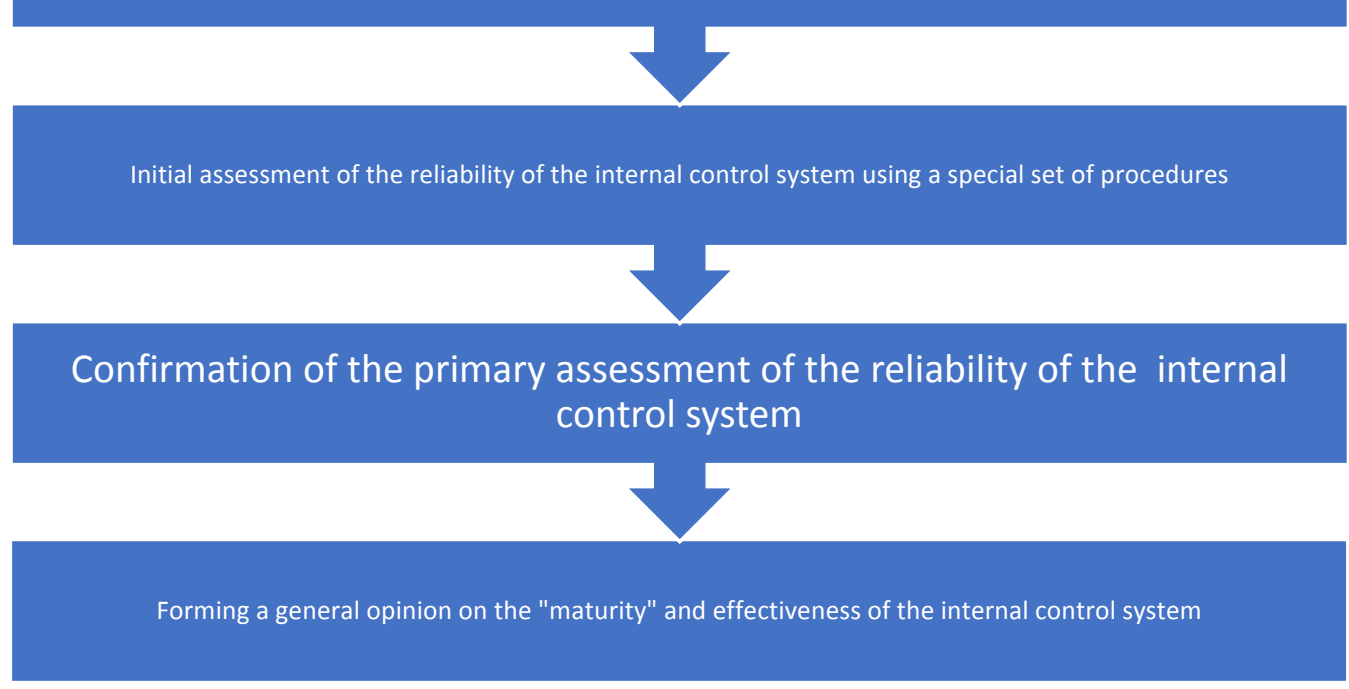

Source: the authors

One of the purposes of developing a high-quality internal control system is risk management. The risks of accounting system of company can be presented in two main aspects:

- from the position of an internal user of information, who receive false information about the state of affairs of an economic entity and make unjustified management decisions;

- from the point of view of external users of information who risk certain funds by making investments in the presence of false information.

In the process of evaluating the internal control system it is necessary to analyze the following indicators:

- the coverage of the internal control system of all business transactions recorded in accounting;

- the number of violations detected by the internal control system in the accounting system as a whole and for individual sections of the accounting process;

- the level of automation of the internal control system;

- the degree of legal and informational support of the internal control system;

- the number of identified misstatements in the process of applying internal control procedures;

- the degree of involvement of the management of the business entity in conducting internal control procedures.

\section{Conclusions}

Thus, we can conclude that the presence of a well-built internal control system is an important tool for improving the effectiveness of the company's functioning. It is necessary to regularly evaluate the internal control system to improve its effectiveness by identifying reserves in this area of management. In addition, risk management is one of the key functions of the internal control system in conditions of varying external impact. Evaluation of the internal control system is aimed at achieving a number of goals that contribute to improving the quality of the 
management and increasing the efficiency of its functioning. The main purpose of using the internal control system is to improve the safety of material and financial resources of the company, as well as to ensure the most complete and reliable reflection of information about economic activities in accounting.

\section{Bibliographic references}

Drury, C. (2017). Management and cost accounting. Boston, USA: Cengage

Egorova I. S. (2015). Risk assessment of the effectiveness of the organization of the internal control system of an economic entity. Innovative development of the economy. 5 (29), 55-65.

Makarenko S. A. (2018). Evaluation of the effectiveness of the internal control system functioning. Business and design review. 4 (12), 8.

Maksimova G. V. (2017) Evaluation of the internal control system / G. V. Maksimova, K. A. Karetnikov // Proceedings of the Baikal state University. 27. 3, 372-379.

Quintero Quintero, Wilder; Navarro Claro, GennyTorcoroma; Arévalo Ascanio, José Gregorio (2019). Management accounting tools in decision making: An analysis in the commercial sector. RevistaEspacios. 40 (№ 10), 27. Retrieved from: https://www.revistaespacios.com/a19v40n10/19401027.html

Samoilova T. V. (2015). Principles of organization and methodological approaches in the assessment of the internal control system. Collected papers: Innovative economy: from theory to practice. 398-403.

Uzlov M. S. (2016). Analysis of the control environment when evaluating the internal control system of the enterprise. Modern science: current problems and ways to solve them. 1 (23). 142-146.

Zaitseva O. P. (2016). Accounting and analysis as an information basis for internal control in agricultural companys. Human science: Humanitarian research. 3 (25), 179-187.

Zelenskaya T. M. (2016). Assessment of economic risks as a separate function of the internal control system. Current trends in the development of science and technology. 5-7, 89-91.

Esta obra está bajo una Licencia Creative Commons

Attribución-NoCommercial 4.0 International

(cc) EYY-NO 